\title{
SENGKETA LAUT CINA SELATAN DALAM PERSPEKTIF HUKUM INTERNASIONAL
}

\author{
Edmondus Sadesto Tandungan \\ Universitas Kristen Indonesia Paulus, edmondus@ukipaulus.ac.id
}

\begin{abstract}
Abstrak
Kawasan Laut Cina Selatan merupakan salah satu wilayah perairan terluas di dunia dan memiliki peran yang strategis baik dari segi ekonomi, politik dan keamanan sehingga menjadikan kawasan ini memiliki potensi yang besar yang dapat dimanfaatkan oleh negara-negara di sekitar kawasan ini. Konsesuensi dari besarnya kepentingan berbagai negara di kawasan ini, adalah semakin besar juga potensi sengketa yang lahir dari situasi tersebut. Artikel ini menganalisis beberapa sengketa yang terjadi di Laut Cina Selatan dari sudut pandang hukum internsional. Tujuan artikel ini adalah untuk mengetahui langkah yang diambil oleh negara dalam menyelesaikan sengketa hukum internasional tersebut. Melalui analisis dalam artikel ini ditemukan bahwa dalam persepektif hukum internasional, sengketa Laut China Selatan bersumber dari perbedaan prinsip dalam penentuan batas wilayah laut. Selain itu, melalui analisis artikel ini pula ditemukan beberapa langkah dan upaya yang dapat ditempuh oleh negara yang bersengketa untuk menyelesaikan sengketa Laut China Selatan.
\end{abstract}

Kata Kunci : Laut Cina Selatan; Sengketa Internasional; Hukum Internasional

\begin{abstract}
The South China Sea Region is one of the largest waters in the world and has a strategic role both in terms of economy, politics and security so as to make this region have great potential that can be utilized by countries around the region. The consequences of many interests in this region is potential conflict form many state. This article analyzes several disputes that occur in the South China Sea based on international law. The purpose of this article is to find out the steps taken by states to resolving these international legal disputes. Through the analysis in this article it was found that in the perspective of international law, the dispute over the South China Sea was sourced from differences of principles in determining maritime boundaries. The analysis of this article also found several steps and efforts that can be taken by the disputing countries to resolve the South China Sea dispute.
\end{abstract}

Keywords : South China Sea; International Dispute; International Law

\section{Pendahuluan}

Dalam konteks kesejarahan, laut memiliki berbagai fungsi, yaitu sebagai sumber makanan bagi umat manusia, sebagai alur perdagangan, sarana rekreasi, bahkan sebagai alat pemersatu dan pemisah bangsa. Praktek yang dilakukan oleh berbagai bangs pada zaman kuno hingga saat ini menunjukkan bahwa laut dapat dan memang pernah dimiliki oleh negara, walaupun seringkali kepemilikan tersebut harus dapat memperhitungkan kepentingan masyarakat internasional. ${ }^{1}$ Seiring perjalanan waktu, hukum internasional mengalami perkembangan yang sangat

\footnotetext{
${ }^{1}$ Hasjim Djalal, (1979), Perjuangan Indonesia Di Bidang Hukum Laut, Cetakan Pertama, Binacipta, Bandung, hal. 11
} 
siginifikan mengenai pengaturan laut, yang mana hal ini terlihat melalui diselenggarakannya berbagai konferensi internasional untuk merumuskan aturanaturan mengenai hukum laut internasional.

Sebagai common heritage of mankind, laut merupakan warisan bersama bagi umat manusia yang mana setiap negara berhak untuk memanfaatkan sumber daya laut bagi kepentingannya. Hal inilah yang juga dapat memicu potensi konflik jika setiap negara saling mengklaim laut tanpa batas serta adanya sebuah aturan yang mengatur hak dan kewajiban setiap negara tentang batas laut, di mana hal ini juga berkaitan erat dengan keamanan dan kedaulatan sebuah negara. ${ }^{2}$ Konflik wilayah laut yang timbul dikarenakan batas wilayah yang berdekatan atau berbatasan, di mana masing-masing negara yang bersengketa menggunakan prinsip yang berbeda mengenai penetapan batas wilayah. Salah satu konflik yang cukup menyita perhatian dunia internasional adalah sengketa Laut Cina Selatan, di mana sengketa ini melibatkan beberapa negara, yaitu Tiongkok, Indonesia, Taiwan, Filipina, Brunei Darussalam, Malaysia, dan Vietnam.

Kawasan Laut Cina Selatan sebagai salah satu wilayah perairan terluas di dunia memiliki peran yang sangat strategis, baik dari segi ekonomi, politik dan keamanan, sehingga menjadikan kawasan ini memiliki potensi kerja sama yang besar yang dapat dimanfaatkan oleh negara-negara di sekitar kawasan ini. Sumber daya alam yang tersedia di kawasan LAut Cina Selatan pun sangat besar, di mana menurut data United States Energy Information Administration (EIA), potensi sumber daya alam di Laut China Selatan berupa cadangan minyak bumi sebesar 11 Milyar barrel dan gas alam yang mencapai 190 Trilyun kaki kubik (Tfc) serta cadangan hidrokarbon yang sangat penting sebagai pasokan energi. Sedangkan menurut konsultan energi, Wood Mackenzie, terdapat cadangan minyak dan gas sebanyak 2,5 Milyar barel di kawasan tersebut. ${ }^{3}$ Selain memiliki peran strategis sebagai jalur perdagangan, kawasan Laut Cina Selatan juga menjadi jalur komunikasi internasional yang menghubungkan antara Samudera Hindia dan Samudra Pasifik yang menjadikannya sebagai jalur tersibuk di dunia. Kawasan laut ini merupakan lalu lintas perdagangan internasional yang bernilai tak kurang dari 5,3 triliun dolar AS setiap tahunnya. ${ }^{4}$

Sengketa Laut Cina Selatan bermula dari pernyataan Pemerintah Republik Rakyat China yang mengklaim seluruh wilayah perairan Laut Cina Selatan. Klaim atas wilayah tersebut oleh pemerintah Republik Rakyat Cina didasarkan atas prinsip Nine Dash Line. Prinsip Nine Dash Line merupakan Sembilan titik imajiner yang menunjukkan klaim China atas hampir seluruh Laut Cina Selatan. Berdasarkan

\footnotetext{
2 Japanton Sitohang, (2008), Perbatasan wilayah laut Indonesia di Laut China Selatan : Kepentingan Indonesia di Perairan Natuna, Lembaga IImu Pengetahuan Indonesia, Pusat Penelitian Politik, Jakarta, hal. 27-28

${ }^{3}$ Laut China Selatan, Perairan Menggiurkan Sumber Sengketa 6 Negara, dalam http://internasional.kompas.com/read/2016/07/13/17401251/laut.china.selatan.perairan.menggiurkan.sumb er.sengketa.6.negara?page=all

${ }^{4}$ Ibid
} 
prinsip tersebut membuat Cina menyatakan status pulau-pulau yang berada di kawasan Laut Cina Selatan masuk dalam wilayah teritorialnya. Hal ini membuat negara-negara di sekitar kawasan tersebut seperti Filipina, Vietnam, Taiwan, Brunei Darussalam dan Malaysia memberikan reakksi keras karena dianggap telah merugikan kepentingan mereka yang juga mengklaim sebagian wilayah Laut Cina Selatan merupakan bagian dari Zona Ekonomi Ekslusif mereka. Sengketa internasional Laut Cina Selatan pada dasarnya merujuk kepada wilayah kawasan laut dan daratan di dua gugusan kepulauan Paracel dan Spratly. Negara-negara kawasan yang terlibat dalam konflik Laut Cina Selatan pada umumnya menggunakan dasar historis dan geografis dalam memperebutkan kepemilikan atas kawasan laut dan dua gugusan kepulauan di wilayah Laut Cina Selatan.

China misalnya, mengklaim wilayah sengketa tersebut berdasarkan kepemilikan bangsa China atas kawasan laut dan dua gugusan kepulauan Paracel dan Spratly sejak 2000 tahun yang lalu. Kemudian Pemerintah China mengklaim telah mengeluarkan peta yang merinci kedaulatan China atas Laut China Selatan pada tahun 1947, yang dikenal dengan istilah Nine Dash Line. ${ }^{5}$ Di sisi lain, negara lain yang bersitegang dengan China yaitu Filipina, Vietnam, Taiwan, Brunei Darussalam, dan Malaysia juga mengklain bahwa sebagian wilayah laut Cina Selatan merupakan Zona Ekonomi Eksklusifnya berdasarkan pendekatan geografis yang diakui oleh Konvensi Hukum Laut 1982. Ketegangan dalam sengketa internasional bahkan kerap menimbulkan bentrokan fisik dengan menggunakan kekuatan militer. Upaya konfrontatif tersebut bahkan dikhawatirkan akan dapat menimbulkan pengaruh tidak hanya pada negara-negara yang bersengketa, melainkan juga bagi negaranegara yang di sekitar kawasan Laut Cina Selatan yang tidak bersengketa.

Indonesia sebagai negara yang tidak terlibat dalam konflik Laut Cina Selatan kini mulai terseret ke dalam pusaran konflik tersebut dikarenakan China juga memasukkan perairan natuna di Kabupaten Natuna sebagai wilayah maritimnya berdasarkan klaim Nine Dash Line. Hal tersebut membuat Indonesia mengeluarkan protes keras atas tindakan China yang memasukkan perairan Kabupaten Natuna sebagai wilayah maritimnya. Perairan Natuna yang menjadi Zona Ekonomi Eksklusif (ZEE) Indonesia diklaim oleh China sebagai kawasan perikanan tradisionalnya, ini menyebabkan banyak nelayan-nelayan China yang secara bebas menangkap ikan di kawasan tersebut yang kemudian merugikan pihak Indonesia. Ekspansi China di kawasan Laut Cina Selatan secara agresif dapat merubah posisi Indonesia yang awalnya netral dalam sengketa Laut Cina Selatan menjadi berlawanan dengan China. Hal ini bukan hanya karena klaim China atas perairan Natuna, tapi juga karena

\footnotetext{
${ }^{5}$ Poltak Partogi Nainggolan, (2013), Konflik Laut China Selatan dan Implikasinya Terhadap Kawasan, P3DI Setjen DPR Republik Indonesia, Jakarta, hal. 8
} 
insiden-insiden yang mengusik kedaulatan Indonesia di perairan Natuna yang melibatkan kapal penjaga dari China. ${ }^{6}$

\section{Metode}

Penulisan artikel ini menggunakan metode penelitian hukum dengan pendekatan yuridis normatif dengan mengacu pada norma-norma hukum internasional. Data yang digunakan dalam artikel ini adalah data sekunder berupa bahan hukum primer yaitu norma hukum internasional yaitu Konvensi Hukum Laut 1982, dan bahan hukum sekunder yaitu literatur berupa buku, jurnal, dan artikel terkait. Analisis data dalam artikel ini menggunakan analisis kualitatif dengan mendeskripsikan fakta-fakta yang ada, kemudian dilakukan analisis berdasarkan norma hukum internasiona maupun teori yang ada.

\section{Konflik Laut Cina Selatan Sebagai Sengketa Internasional}

Sebagaimana telah disebutkan pada bagian terdahulu bahwa Kawasan Laut Cina Selatan merupakan wilayah laut yang memiliki potensi sangat besar di bidang ekonomi, politik, dan pertahanan, sehingga dapat memicu sengketa yang didasarkan atas kepentingan berbagai negara di kawasan tersebut. Dalam perspektif Hukum Internasional, sengketa internasional (International Dispute) merupakan suatu suatu perselisihan antara subjek-subjek hukum internasional mengenai fakta, hukum, atau politik dimana tuntutan atau pernyataan satu pihak ditolak, dituntut balik atau diingkari oleh pihak lainnya. ${ }^{7}$ Sengketa internasional terjadi jika perselisihan tersebut melibatlan pemerintah, lembaga juristic person (badan hukum) atau individu dalam bagian dunia yang berlainan karena :

a. Kesalahpahaman tentang suatu hal;

b. Salah satu pihak sengaja melanggar hak/kepentingan negara lain;

3. Dua negara berselisih pendirian tentang suatu hal;

4. Pelanggaan hukum atau perjanjian internasional.

Sengketa Laut Cina Selatan yang melibatkan beberapa negara claimant states, yaitu China, Taiwan, Filipina, Malaysia, Brunei Darussalam, dan Vietnam dapat dikatakan sebagai sengketa hukum laut internasional terpanas pada abad in, selain karena melibatkan beberapa negara, juga jangka waktu sengketa yang masih berlangsung hingga saat ini. Sengketa ini pada mulanya terjadi karena pemerintah China menyatakan klaim bahwa mereka memiliki kedaulatan atas hampir seluruh Laut Cina Selatan dengan alasan bahwa nelayan tradisional mereka telah menjelajahi Kepulauan Spratly dan Paracel sejak tahun 200 SM. Bagi China, mereka berhak atas kawasan Laut Cina Selatan didasarkan pada landasan historis dan effective

\footnotetext{
${ }^{6}$ Rizal Dwi Novianto, Dimas Agung Firmansyah, Naufal Adi Pratama, (2020), Penyelsaian Sengketa di Laut Natuna Utara, Jurnal Hukum Bisnis Bonum Commune, v3n1. hal. 71

${ }^{7}$ Huala Adolf, (2004) Hukum Penyelesaian Sengketa Internasional, Sinar Grafika, Jakarta, hal. 1
} 
occupation sejak berabad-abad lamanya. Landasan historis yang dimaksud adalah traditional fishing ground yang merupakan wilayah pencarian ikan yang dilakukan oleh nenek moyang mereka dari sejak jaman dahulu. Sebagai perwujudan dari penegasan klaimnya, Tiongkok melakukan pendudukan terhadap sejumlah pulau atau fitur maritim di kawasan konflik tersebut. ${ }^{8}$

Pada dasarnya klaim atas Laut China Selatan sudah dilakukan China pada tahun 1947 saat pemerintahan China dikuasai oleh Partai Kuomintang dengan menciptakan garis demarkasi yang disebut dengan Eleven Dash Line. Berdasarkan klaim ini China menguasai mayoritas Laut China Selatan termasuk Kepulauan Pratas, Macclesfield Bank serta Kepulauan Spratly dan Paracel yang diperoleh China dari Jepang usai Perang Dunia II. Kemudian, oleh Pemerintah Komunis menyederhanakan peta itu dengan mengubahnya menjadi Nine Dash Line" yang kini digunakan sebagai dasar historis untuk mengklaim hampir semua wilayah perairan seluas 3 juta kilometer persegi itu. ${ }^{9}$ Ketika itu klaim ini pada dasarnya tidak ada pertimbangan politik dan strategik tertentu karenarezim yang berkuasa pada saat itu sibuk membenahi perang saudara dengan rezim komunis. ${ }^{10}$

Nine Dash Line adalah peta teritorial yang membubuhkan Sembilan garis putusputus sebagai penanda atau batas pemisah imajiner yang digunakan pemerintah China untuk mengklaim sebagian besar, yakni 90 persen, wilayah Laut Cina Selatan. Berdasarkan Nine Dash Line, luas wilayah maritime yang diklaim oleh China sebagai traditional fishing ground yaitu seluas 94.000 kilometer persegi. Sayangnya, klaim China tersebut bersinggungan dengan wilayah lima negara lain yang juga mengklaim wilayah tersebut. Dalam hal ini, China melakukan klaim atas Laut Cina Selatan berdasarkan hak sejarah dan bukan berdasarkan fitur tanah sebagaimana dipersyaratkan oleh Konvensi Hukum Laut UNCLOS 1982.

Hingga akhir 2013, klaim China atas Laut Cina Selatan masih belum berubah, dimana klaim China tidak hanya diwujudkan dalam bentuk sikap politik, tetapi juga dalam bentuk lain. Di bidang militer, China sering melakukan aksi patroli di perairan tersebut yang kadang memicu bentrok dengan kapal dari negara lain seperti Vietnam dan Filipina. Di bidang eksplorasi, Cina juga menempatkan peralatan pengeboran di beberapa titik di Laut Cina Selatan. ${ }^{11}$ Enam negara yang terlibat klaim di Laut Cina Selatan memiliki klaim yang saling tumpah tindih. China, Taiwan, dan Vietnam cenderung melakukan klaim wilayah terhadap seluruh Kepulauan Spratly, sementara

\footnotetext{
${ }^{8}$ Hari Utomo, Mitro Prihantoro, Lena Adriana, (2017), Peran Pemerintah Indonesia Dalam Mengelola Konflik Laut China Selatan, Jurnal Prodi Damai dan Resolusi Konflik, v3n3, hal. 68

${ }^{9}$ Laut China Selatan, Perairan Menggiurkan Sumber Sengketa 6 Negara, dalam https://internasional.kompas.com/read/2016/07/13/17401251/laut.china.selatan.perairan.menggiurka n.sumber.sengketa.6.negara?page=all

${ }^{10}$ Zheng Wang, (2015), Asian Survey : Chinesse Disource on the Nine Dash Line: Rights, Interests, and Nationalism" volume 35, number 3, The University of California, hal. 503

${ }^{11}$ Karmin Suharna, (2012), Konflik dan Solusi Laut Cina Selatan dan Dampaknya bagi Ketahanan Nasional, Majalah Ketahanan Nasional, Edisi 94, hal. 33-34.
} 
Malaysia, Filipina, dan Brunei Darussalam hanya menuntut sebagian pulau-pulau dari kepulauan tersebut.

Pada dasarnya terdapat tiga hal yang menjadi alasan utama terjadinya sengketa di Laut Cina Selatan antara enam negara tersebut. Pertama, wilayah laut dan gugusan kepulauan di Laut Cina Selatan yang mengandung sumber kekayaan alam yang sangat besar, meliputi kandungan minyak dan gas bumi serta kekayaan laut lainnya. Kedua, wilayah perairan Laut Cina Selatan yang merupakan wilayah perairan yang menjadi jalur perlintasan aktivitas pelayaran kapal-kapal internasional, terutama jalur perdagangan lintas laut yang menghubungkan jalur perdagangan Eropa, Amerika, dan Asia. Ketiga, pertumbuhan ekonomi yang cukup pesat di Asia, membuat negara-negara seperti China dan negara-negara di kawasan Laut Cina Selatan, bahkan termasuk Amerika Serikat sangat berkeinginan menguasai kontrol dan pengaruh atas wilayah Laut Cina Selatan yang dinilai sangat strategis dan membawa manfaat ekonomis yang sangat besar bagi suatu negara. ${ }^{12}$

\section{Kepentingan Negara atas Laut China Selatan}

Sebagaimana diketahui bahwa beberapa negara yang melakukan klaim atas Laut Cina Selatan memiliki kepentingan di kawasan tersebut. Dari enam negara yang bersitegang, China adalah negara yang paling asertif dan agresif dalam sengketa internasional tersebut, baik melalui penggunaan jalur diplomasi maupun kekuatan lain, seperti kapal ikan, kapal patrol maritime, dan angkatan laut. ${ }^{13}$ Klaim Brunei Darussalam atas Laut Cina Selatan lebih kepada kepentingan hak berdaulat di wilayah perairan yurisdiksinya, khsusnya dalam bidang keamanan navigasi dan pengelolaan sumber daya perikanan dan migas. ${ }^{14}$ Berbeda halnya dengan klaim Vietnam yang menuntut kedaulatan dan hak berdaulat yang sama dengan China di wilayah Kepulauan Paracel dan Spratly serta perairan di sekitarnya berdasarkan sejarah yang sama. Klaim Vietnam pada Kepulauan Spratly dan Laut Cina Selatan didasarkan pada sejarah dan berlandaskan pada Zona Ekonomi Eksklusif dan Landas Kontinen sebagaimana diatur dalam Konvensi Laut Internasional 1982. Vietnam mengklaim gugusan Pulau Paracel ke utara yang saat ini dikuasai China sebagai miliknya. Klaim kedaulatan atas Kepulauan Paracel dan Spratly akan berdampak pada bertambahnya wilayah Zona Ekonomi Eksklusif dan Landas Kontinen Vietnam. Vietnam berkepentingan terhadap kebebasan bernavigasi (freedom of navigation) bagi kapal dagang, kapal tanker, kapal ikan, kapal patroli maritim, dan kapal perang Vietnam. ${ }^{15}$

\footnotetext{
${ }^{12}$ Poltak Partogi Nainggolan, Op.Cit, hal. 10-11

13 Surya Wiranto, (2016), Resolusi Konflik Menghadapi Laut Tiongkok Selatan dari Perspektif Hukum Internasional, PT Leutika Nouvalitera, Yogyakarta, hal. 88

${ }^{14}$ Muhar Junef, (2018), Sengketa Wilayah Maritim di Laut Tiongkok Selatan, Jurnal Penelitian Hukum De Jure, v18n2, hal. 227

15 Ibid, hal. 228
} 
Kepentingan Filipina di kawasan Laut Cina Selatan adalah klaim berdasarkan sejarah, penemuan, kelanjutan wilayah laut, dan kedejatan lokasi (faktor geografis) sebagaimana yang diatur dalam Konvensi Hukum Laut 1982. Dalam hal ini, Filipina mengklaim gugusan Kepulauan Spratly ke selatan sebagai miliknya yang tumpang tindih dengan posisi China. Klaim kedaulatan atas Scarborough Shoal dan Pulau Kelayaan sangat penting bagi Filipina karena akan berdampak pada bertambahnya wilayah Zona Ekonomi Eksklusif dan Landas Kontinen Filipina sebagai negara kepulauan sebagaimana diatur dalam Konvensi Hukum Laut 1982. Perairan sekitar Scarborough Shoal memiliki kandungan minyak yang cukup besar dan Filipina berkepentingan untuk pemenuhan energinya. Kawasan Laut Cina Selatan yang diklaim Filipina memiliki sumber daya perikanan yang cukup besar dan selama ini merupakan daerah operasi kapal-kapal penangkap ikan Filipina. ${ }^{16}$ Malaysia sendiri mengklaim Kepulauan Spratly dan Laut Cina Selatan berdasarkan zona ekonomi ekslusifnya dan kepanjangan dari landas kontinennya seperti yang diatur di dalam Pasal 55 dan Pasal 76 Konvensi Hukum Laut 1982. Klaim Malaysia terhadap beberapa pulau di Kepulauan Spratly yang dinamai Terumbu Layang dan Terumbu Laksamana lebih pada kepentingan hak berdaulat, khususnya dalam bidang keamanan navigasi (safety of navigation) dan pengelolaan sumber daya perikanan dan migas.

Dari sekian negara yang melakukan klaim atas kawasan Laut Cina Selatan, Filipina merupakan negara yang paling keras dalam melakukan penolakan terhadap klaim China atas Laut China Selatan. Sebagai bentuk penolakan tersebut, pada ahun 2013 Filipina mengajukan gugatan ke Permanent Court of Arbitration (PCA) di Den Haag. Dalam putusannya, PCA menyatakan bahwa klaim Nine Dash Line yang digunakan oleh China tidak memiliki landasan hukum, dan reklamasi pulau yang dilakukan Tiongkok tidak akan memberikan hak apapun kepada Pemerintah China serta China dianggap melakukan pelanggaran atas hak-hak kedaulatan Filipina. Selain itu, putusan PCA ini juga menegaskan bahwa China telah menyebabkan kerusakan lingkungan di Laut Cina Selatan dengan membangun pulau-pulau buatan tersebut. ${ }^{17}$ PCA dalam putusannya menetapkan : ".... although Chinese navigators and fishermen, as well as those of other States, had historically made use of the islands in the South China Sea, there was no evidence that China had historically exercised exclusive control over the waters or their resources. The Tribunal concluded that there was no legal basis for China to claim historic rights to resources within the sea areas falling within the nine-dash line".18 Walaupun hasil putusan tersebut mengikat atau legally binding namun PCA sendiri tidak memiliki kekuatan untuk menerapkannya pada negara manapun.

\footnotetext{
${ }^{16}$ Surya Wiranto, Op.cit, hal. 93

${ }^{17}$ Hari Utomo, Mitro Prihantoro, Lena Adriana, Op.cit, hal. 70

${ }^{18}$ PCA Press Release: The South China Sea Arbitration (The Republic of the Philippines v. The Peoples's Republic of China), dalam https://pca-cpa.org/en/news/pca-press-release-the-south-china-sea-arbitration-the-republicof-the-philippines-v-the-peoples-republic-of-china/
} 
Menurut Ahmad Almauduy Amri, Putusan PCA menyatakan bahwa negara tidak boleh mengklaim zona maritim di luar ketentuan yang sudah diatur di dalam Konvensi Hukum Laut 1982, dimana dalam Pasal 121 ayat 1 ditetapkan bahwa :

1. An island is a naturally formed area of land, surrounded by water, which is above water at high tide.

2. Except as provided for in paragraph 3, the territorial sea, the contiguous zone, the exclusive economic zone and the continental shelf of an island are determined in accordance with the provisions of this Convention applicable to other land territory.

3. Rocks which cannot sustain human habitation or economic life of their own shall have no exclusive economic zone or continental shelf.

Meskipun PCA telah mengeluarkan putusan terkait atas gugatan Filipina, namun China memutuskan untuk tidak mematuhi hasil putusan PCA tersebut. Pernyataan tersebut langsung disampaikan oleh Presiden Tiongkok, Xi Jinpinng yang menyatakan bahwa kedaulatan territorial dan hak maritim China di Laut Cina Selatan tidak akan terpengaruh oleh hasil putusan ini dalam segala hal. Bahkan, China terus melakukan penguatan klaim atas Laut Cina Selatan dengan beragai upaya, seperti rencana pemanfaatan pulau-pulau buatan di Laut China Selatan sebagai lokasi pariwisata, pembiayaan pencarian bukti-bukti arkeologis penguasaan eksklusif China di Laut Cina Selatan, melakukan reklamasi yang jumlahnya melebihi total rekalamasi yang pernah dilakukan oleh claimant states lainnya dan pembangunan infrastruktur termasuk landasan pesawat militer. ${ }^{19}$

\section{Konvensi Hukum Laut 1982 dan Upaya Penyelesaian Sengketa Laut Cina Selatan}

Konvensi Perserikatan Bangsa-Bangsa tentang Hukum Laut atau yang biasa disebut dengan Konvensi Hukum Laut Internasional 1982 (UNCLOS 1982) merupakan perjanjian internasional yang dihasilkan dari Konferensi Perserikatan Bangsa-Bangsa tentang Hukum Laut yang ketiga (UNCLOS III) yang berlangsung dari tahun 1973 sampai dengan tahun 1982. Konvensi Hukum Laut ini mendefinisikan hak dan tanggung jawab negara dalam penggunaan lautan di dunia serta menetapkan pedoman untuk bisnis, lingkungan, dan pengelolaan sumber daya alam laut. Sebagai instrumen hukum internasional, maka Konvensi Hukum Laut 1982 menjadi dasar hukum bagi setiap negara dalam menentukan delimitasi maritim. Oleh karena itu, Konvensi Hukum Laut 1982 menjadi landasan untuk menyelesaikan sengketa internasional yang terkait dengan wilayah maritim suatu negara.

Meskipun Konvensi Hukum Laut 1982 telah memberikan pengaturan mengenai batas wilayah laut suatu negara dan pembagian zona maritim, namun konflik yang terjadi antara dua negara atau lebih terkait dengan batas wilayah masih sering terjadi. Dalam hal terjadi sengketa, Konvensi Hukum Laut 1982 telah mengatur mekanisme penyelesaian sengketa, yang terdiri dari tiga bagian. Pada bagian I

\footnotetext{
${ }^{19}$ Dewi Fortuna Anwar, ASEAN dan Isu Laut China Selatan, Makalah dipresentasikan pada Seminar Laut China Selatan di Universitas Pertahanan, Oktober 2016.
} 
mengatur bahwa penyelesaian sengketa dilakukan melalui kesepakatan damai antara para pihak. Bagian II mengatur prosedur penyelesaian sengketa yang memaksa demi menghasilkan keputusan yang mengikat yang berlaku apabilan prosedur pada bagian I tidak memberikan jalan keluar atas sengketa tersebut. Bagian III mengatur beberapa pembatasan dan pengecualian dalam yurisdiksi untuk prosedur yang diatur dalam Bagiam II.

Dalam sengketa Laut Cina Selatan, salah satu pihak yang bersengketa yaitu Filipina telah mengajukan gugatan ke PCA dan dalam putusannya, PCA tidak mengakui klaim yang dilakukan oleh China. Terkait dengan upaya yang dilakukan Filipina tersebut, sesuai dengan Pasal 287 ayat (3), baik Filipina maupun China harus tunduk pada prosedur arbitrase yang diatur dalam Annex VII Konvensi Hukum Laut 1982 tentang Arbitrase. Meskipun putusan yang dikeluarkan PCA bersifat final, namun tidak memiliki kekuatan mengikat yang bersifat memaksa. Dalam hal ini, pelaksanaan putusan arbitrase kembali pada itikad baik negara yang bersengketa. ${ }^{20}$ Sebagaimana dipaparkan sebelumnya, bahwa China sendiri menolak untuk menerima putusan yang dikeluarkan oleh PCA.

Penyelesaian sengketa wilayah maritim hanya dapat dilakukan berdasarkan hukum internasional atau yang dalam hal ini adalah Konvensi Hukum Laut 1982, dan dalam konvensi tersebut tidak mengenal delimitasi batas maritim yang didasarkan atas aspek sejarah. Hal ini berarti bahwa sengketa Laut Cina Selatan dapat diselesaikan melalui prosedur Mahkamah Internasional, mengingat China merupakan negara yang melakukan ratifikasi Konvensi Hukum Laut 1982 dan dengan demikian terikat pada Konvensi tersebut.

Upaya lain yang dapat dilakukan untuk menyelesaikan sengketa tersebut sekaligus menghindari potensi konflik yang dapat timbul adalah melalui perundingan secara damai baik secara bilateral maupun multilateral dan juga melakukan kerjasama-kerjasama yang lazim digunakan mengelola konflik regional dan internasional. Salah satu yang telah dilakukan dalam forum regional adalah upaya ASEAN mengingat beberapa negara yang menjadi pihak dalam sengketa Laut China Selatan adalah anggota ASEAN. Negara-negara anggota ASEAN melalui Forum Regional ASEAN sejak awal dekade 1990-an telah mengambil inisiatif untuk merespons potensi meningkatnya konflik di Laut Cina Selatan. Pada 22 Juli 1992 di Manila-Filipina, para Menteri Luar Negeri dari negara-negara anggota ASEAN mengeluarkan ASEAN Declaration of Conduct on the South China Sea. Deklarasi ini berisi seruan kepada semua pihak untuk menyelesaikan sengketa dengan damai dan diterapkannya prinsip Treaty of Amity and Cooperation. ${ }^{21}$ Kesepakatan lain yang

\footnotetext{
${ }^{20}$ Miftah Hanifah, Nanik Trihastuti, Peni Susetyorini, (2017), Penyelesaian Sengketa Gugatan Filipina Terhadap China Mengenai Lau China Selatan Melalui Permanent Court of Arbitration, Diponegoro Law Journal, v6n1, hal. 8

21 Sengketa di Kawasan Laut Natuna Utara, dalam https://indonesia.go.id/narasi/indonesia-dalamangka/politik/sengketa-di-kawasan-laut-natuna-utara
} 
berhasil dicapai adalah ASEAN dan China sepakat mengeluarkan Declaration on Conduct of the Parties in the South China Sea (DOC). Deklarasi ini berisikan komitmen ASEAN-Tiongkok untuk mematuhi prinsip-prinsip hukum internasional, menghormati freedom of navigation di Laut Cina Selatan, dan komitmen untuk menyelesaikan sengketa secara damai. Terakhir, pada November 2019 dirumuskan pernyataan bersama pemimpin negara anggota ASEAN dan China, yang menghasilna 18 pernyataan sebagai hasil kesepakatan bersama. Pada poin kedelapan belas, memastikan pentingnya menjaga dan mengutamakan perdamaian, keamanan, stabilitas, keselamatan, dan kebebasan navigasi masuk dan keluar di kawasan Laut Cina Selatan. Tujuannya ialah memahami bersama kemanfaatan dari Laut Cina Selatan sebagai kawasan yang damai, stabil, dan makmur. Pernyataan bersama ini juga kembali menggarisbawahi pentingnya implementasi secara efektif dan sepenuhnya atas Declaration on Conduct of the Parties in the South China Sea 2002.22 Langkah maju yang diperoleh adalah pernyataan bersama forum ASEAN-China tersebut juga mendorong tercapainya resolusi damai terhadap penyelesaian sengketa dengan merujuk pada Konvensi Hukum Laut 1982.

\section{Kesimpulan}

Sengketa Laut China Selatan yang berlangsung selama puluhan tahun hingga saat ini belum menemukan penyelesaian dan menjadi konflik berkepanjangan di antara negara yang bersengketa. Sengketa ini ditimbulkan oleh perbedaan pandangan dan prinsip mengenai penentuan batas wilayah, di satu sisi China menggunakan aspek sejarah, sedangkan lima negara lain yang bersengketa selain menggunakan aspek sejarah juga menggunakan Konvensi Hukum Laut 1982 sebagai dasar penentuan batas wilayah laut. Dalam konteks hukum internasional, menjadi sebuah kewajiban bagi setiap negara yang meratifikasi Konvensi Hukum Laut 1982 untuk menghormati dan tunduk pada konvensi tersebut sebagai kesepakatan masyarakat internasional. Menjadi suatu kewajiban bagi setiap negara untuk menentukan batas maritimnya dan menyelesaikan sengketa laut berdasarkan konvensi tersebut. Dalam hal ini, itikad baik dari negara yang bersengketa menjadi modal utama dalam penyelesaian sengketa Laut China Selatan, sebagaimana yang dituangkan dalam Konvensi Hukum Laut 1982, di mana penyelesaian sengketa dapat ditempuh melalui prosedur kesepakatan damai. Jika hal tersebut tidak dapat menemukan hasil, maka langkah yang dapat ditempuh adalah melalui prosedur Mahkamah Internasional. Selain itu, upaya lain yang dapat dilakukan adalah malalui jalur diplomasi regional, seperti yang dilakukan ASEAN dengan China sebagai bentuk upaya kesepakatan damai sebagaimana yang diatur dalam Konvensi Hukum Laut 1982.

22 Ibid 


\section{REFERENSI}

Hari Utomo, Mitro Prihantoro, Lena Adriana, (2017), Peran Pemerintah Indonesia Dalam Mengelola Konflik Laut China Selatan, Jurnal Prodi Damai dan Resolusi Konflik, v3n3

Hasjim Djalal, (1979), Perjuangan Indonesia Di Bidang Hukum Laut, Cetakan Pertama, Bandung: Binacipta

Huala Adolf, (2004), Hukum Penyelesaian Sengketa Internasional, Jakarta : Sinar Grafika Japanton Sitohang, (2008), Perbatasan wilayah laut Indonesia di Laut China Selatan : Kepentingan Indonesia di Perairan Natuna, Jakarta : Lembaga Ilmu Pengetahuan Indonesia, Pusat Penelitian Politik

Karmin Suharna, (2012), Konflik dan Solusi Laut Cina Selatan dan Dampaknya bagi Ketahanan Nasional, Majalah Ketahanan Nasional, Edisi 94

Miftah Hanifah, Nanik Trihastuti, Peni Susetyorini, (2017), Penyelesaian Sengketa Gugatan Filipina Terhadap China Mengenai Lau China Selatan Melalui Permanent Court of Arbitration, Diponegoro Law Journal, v6n1

Muhar Junef, (2018), Sengketa Wilayah Maritim di Laut Tiongkok Selatan, Jurnal Penelitian Hukum De Jure, v18n2

Poltak Partogi Nainggolan, (2013), Konflik Laut China Selatan dan Implikasinya Terhadap Kawasan, Jakarta : P3DI Setjen DPR Republik Indonesia

Rizal Dwi Novianto, Dimas Agung Firmansyah, Naufal Adi Pratama, (2020), Penyelsaian Sengketa di Laut Natuna Utara, Jurnal Hukum Bisnis Bonum Commune, v3n1

Surya Wiranto, (2016), Resolusi Konflik Menghadapi Laut Tiongkok Selatan dari Perspektif Hukum Internasional, Yogyakarta: PT Leutika Nouvalitera

Zheng Wang, (2015), Asian Survey : Chinesse Disource on the Nine Dash Line: Rights, Interests, and Nationalism" volume 35, number 3, The University of California

Dewi Fortuna Anwar, ASEAN dan Isu Laut China Selatan, Makalah dipresentasikan pada Seminar Laut China Selatan di Universitas Pertahanan, Oktober 2016

http://internasional.kompas.com/read/2016/07/13/17401251/laut.china.selatan.p erairan.menggiurkan.sumber.sengketa.6.negara?page $=$ all,

https:/ / pca-cpa.org/en/ news/ pca-press-release-the-south-china-sea-arbitrationthe-republic-of-the-philippines-v-the-peoples-republic-of-china/ https://indonesia.go.id/narasi/indonesia-dalam-angka/politik/sengketa-dikawasan-laut-natuna-utara 